\title{
FAKTOR-FAKTOR YANG BERPENGARUH TERHADAP KEPATUHAN WAJIB PAJAK PASCA PENERAPAN PERATURAN PEMERINTAH NOMOR 23 TAHUN 2018
}

\author{
FACTORS INFLUENCING TAXPAYER COMPLIANCE AFTER \\ IMPLEMENTATION OF GOVERNMENT REGULATION NUMBER 23 \\ OF 2018
}

\author{
Santuo \\ Kantor Pelayanan Pajak Pratama Bulukumba - Direktorat Jenderal Pajak \\ email: santo.statistika@gmail.com
}

\begin{abstract}
Abstrak
Kepatuhan wajib pajak merupakan salah satu faktor penentu dalam pencapaian penerimaan pajak. Pemerintah telah melakukan berbagai upaya untuk meningkatkan kepatuhan wajib pajak. Salah satunya adalah dengan menerbitkan Peraturan Pemerintah Nomor 23 Tahun 2018. Penelitian ini bertujuan untuk mengetahui pengaruh perubahan tarif pajak, penerapan asas keadilan perpajakan dan pelaksanaan sosialisasi perpajakan terhadap kepatuhan wajib pajak pada Kantor Pelayanan Pajak Pratama Bulukumba setelah penerapan Peraturan Pemerintah Nomor 23 Tahun 2018. Jumlah sampel dalam penelitian ini sebanyak 120 wajib pajak yang terdaftar pada Kantor Pelayanan Pajak Pratama Bulukumba, yang ditentukan dengan teknik cluster random sampling yaitu dengan mengambil responden secara acak dari tiga kabupaten yang ada di wilayah kerja Kantor Pelayanan Pajak Pratama Bulukumba. Penelitian ini menggunakan kuesioner sebagai instrumen pengumpulan data. Analisis data menggunakan analisis regresi linear berganda dengan uji hipotesis parsial dan simultan. Hasil penelitian menunjukkan bahwa tarif pajak, asas keadilan perpajakan dan sosialisasi perpajakan berpengaruh secara positif dan signifikan terhadap kepatuhan wajib pajak. Hal ini berarti bahwa kepatuhan wajib pajak pada Kantor Pelayanan Pajak Pratama Bulukumba setelah penerapan Peraturan Pemerintah Nomor 23 Tahun 2018 secara mayoritas dipengaruhi oleh perubahan tarif pajak, penerapan asas keadilan perpajakan dan pelaksanaan sosialisasi perpajakan atas penerapan peraturan tersebut serta selebihnya dipengaruhi oleh faktor lain yang tidak dimasukkan dalam model penelitian ini.
\end{abstract}

Kata Kunci: kepatuhan wajib pajak, tarif pajak, keadilan perpajakan, sosialisasi perpajakan

\begin{abstract}
Taxpayer compliance is one of the determining factors in achieving tax revenue. The government has made efforts to improve taxpayer compliance. One of the efforts is by issuing Government Regulation Number 23 of 2018. This study aims to determine the effect of the tax rate changes, the application of the principle of tax fairness and tax socialization application on taxpayer compliance in the Bulukumba Tax Office after the implementation of Government Regulation Number 23 of 2018. The number of samples/respondents in this study are 120 taxpayers at Bulukumba Tax Office, which determined by cluster random sampling technique from three districts in the Bulukumba Tax Office Area. This study used questionnaire as data collection instrument. For Data analysis, researcher used multiple linear regression analysis with partial and simultaneous hypothesis tests. The results indicate that tax rates, the principle of tax fairness and tax socialization had a positive and significant effect on taxpayer compliance. This means that taxpayer compliance at Bulukumba Tax Office after the
\end{abstract}


implementation of Government Regulation Number 23 of 2018 generally influenced by the tax rate changes, the application of the principle of tax fairness and tax socialization and the others influenced by other factors not included in this research model.

Keywords: taxpayer compliance, tax rate, tax fairness, tax socialization

\section{PENDAHULUAN}

\begin{abstract}
Indonesia merupakan negara berkembang yang melakukan pembangunan nasional disegala bidang terutama bidang ekonomi. Pembangunan nasional dapat terlaksana dengan baik apabila pemerintah memiliki sumber dana yang cukup untuk membiayai pembangunan tersebut. Salah satu sumber utama dana pembangunan nasional adalah penerimaan pajak. Pajak adalah iuran kepada kas negara berdasarkan undangundang (yang dapat dipaksakan) dengan tiada mendapat jasa timbal (kontraprestasi) yang langsung dapat ditunjukkan dan yang digunakan untuk membayar pengeluaran umum (Mardiasmo, 2016).
\end{abstract}

Sistem perpajakan di Indonesia menggunakan prinsip self assessment system. Ibrahim dan Arum (2018) menyatakan bahwa self assessment system memberikan kepercayaan kepada wajib pajak untuk bertanggung jawab dalam menetapkan kewajiban pajaknya dan kemudian secara akurat dan tepat waktu membayar dan melaporkan pajak tersebut. Sehingga bisa dikatakan bahwa wajib pajak menetukan sendiri besarnya pajak yang terutang. Dalam pelaksanaan self assessment system, pemerintah melalui Direktorat Jendral Pajak memiliki peran untuk melakukan pengawasan, pelayanan, pembinaan serta pengenaan sanksi perpajakan.

Pajak yang merupakan salah satu sumber utama penerimaan negara memiliki peranan yang cukup besar dalam berlangsungnya pembangunan. Oleh karena itu, pemerintah melalui Direktorat Jenderal Pajak telah melakukan berbagai upaya agar dapat meningkatkan penerimaan negara dari sektor pajak. Ramadiansyah et al. (2014) menyatakan bahwa berbagai upaya dilakukan oleh Dirjen Pajak agar dapat meningkatkan penerimaan pajak dengan melakukan reformasi pajak yang bertujuan agar sistem perpajakan Indonesia dapat mengalami penyederhanaan tarif pajak, penghasilan kena pajak dan sistem pemungutan pajak. Salah satu upaya yang dilakukan oleh pemerintah untuk meningkatkan penerimaan pajak adalah dengan menerbitkan kebijakan atau peraturan perundang-undangan di bidang perpajakan.

Pada tahun 2018, pemerintah telah menerbitkan Peraturan Pemerintah Nomor 
23 Tahun 2018. Peraturan ini berlaku secara efektif pada tanggal 1 juli 2018 dan menggantikan peraturan sebelumnya yaitu Peraturan Pemerintah Nomor 46 Tahun 2013 yang dinilai memiliki beberapa kekurangan yang perlu disesuaikan dengan kondisi perekonomian saat ini. Dalam Peraturan Pemerintah Nomor 23 Tahun 2018 ini, pemerintah telah memutuskan untuk menurunkan tarif pajak penghasilan final menjadi $0,5 \%$ yang sebelumnya berlaku $1 \%$. Meskipun demikian, ketentuan ini bersifat opsional karena wajib pajak dapat memilih untuk mengikuti skema tarif pajak penghasilan final $0,5 \%$ ataupun menggunakan skema ketentuan tarif pajak penghasilan normal secara umum sebagaimana diatur dalam Pasal 17 Undang-Undang Nomor 36 Tahun 2008 tentang Pajak Penghasilan. Pada peraturan sebelumnya, wajib pajak tidak diberikan kesempatan untuk memilih menggunakan skema tarif pajak penghasilan final atau tarif pajak penghasilan secara umum. Dengan adanya perubahan ketentuan dalam Peraturan Pemerintah Nomor 23 Tahun 2018 ini, diharapkan dapat meningkatkan kepatuhan wajib pajak Usaha, Mikro, Kecil dan Menengah (UMKM) dalam memenuhi kewajiban perpajakannya.

Mustofa et al. (2016) menyatakan bahwa kepatuhan wajib pajak adalah sejauh mana wajib pajak dapat melaksanakan kewajiban perpajakannya dengan baik dan benar sesuai peraturan perpajakan. Dengan meningkatnya kepatuhan wajib pajak, maka secara tidak langsung memiliki pengaruh kepada meningkatnya penerimaan pajak.

Terdapat beberapa kebijakan yang diatur oleh pemerintah dalam Peraturan Pemerintah Nomor 23 Tahun 2018 yang diharapkan bisa meningkatkan kepatuhan wajib pajak. Salah satu kebijakan tersebut adalah kebijakan penurunan tarif pajak dari $1 \%$ menjadi $0,5 \%$. Mustofa et al. (2016) menyatakan bahwa tarif pajak adalah dasar pengenaan pajak yang digunakan untuk menentukan jumlah pajak terutang dari suatu objek pajak. Lazuardini et al. (2018) menyatakan bahwa tarif pajak berpengaruh terhadap kepatuhan wajib pajak. Atawodi dan Ojeka (2012) menyatakan bahwa kepatuhan wajib pajak secara signifikan tidak dipengaruhi oleh tarif pajak. Hal ini diperkuat oleh Ananda et al. (2015) dan Tawas et al. (2016) yang menyatakan bahwa tarif pajak berpengaruh terhadap meningkatnya kepatuhan wajib pajak. Hasil penelitian berbeda dikemukakan oleh Yusro dan Kiswanto (2014) bahwa kepatuhan wajib pajak tidak dipengaruhi oleh tarif pajak. Dengan demikian, dapat dikatakan bahwa tarif pajak dapat berpengaruh maupun tidak 
berpengaruh terhadap kepatuhan wajib pajak.

Kebijakan lainnya yang diatur dalam Peraturan Pemerintah Nomor 23 Tahun 2018 adalah adanya skema opsional. Skema opsional adalah wajib pajak diberikan pilihan untuk memilih menggunkan tarif pajak penghasilan final 0,5\% sesuai Peraturan Pemerintah Nomor 23 Tahun 2018 atau menggunakan tarif pajak penghasilan secara umum sesuai dengan ketentuan Undang-Undang Nomor 36 Tahun 2008. Wajib pajak yang memilih untuk menggunakan tarif pajak penghasilan secara umum, terlebih dahulu menyampaikan pemberitahuan tertulis kepada Kantor Pelayanan Pajak tempat wajib pajak terdaftar. Dengan adanya kebijakan tersebut, maka wajib pajak bisa memperhitungkan jumlah pajak penghasilan yang terutang sesuai dengan kemampuan masing-masing. Jika wajib pajak menganggap jumlah pajak penghasilan yang terutang lebih besar jika menggunakan tarif $0,5 \%$ dari peredaran bruto, maka wajib pajak bisa menyelenggarakan pembukuan dan menghitung keuntungan bersih. Sehingga pajak penghasilan yang terutang dikenakan dari keuntungan bersih, bukan dari jumlah peredaran bruto. Kebijakan perpajakan ini sejalan dengan penerapan asas keadilan dalam pelaksanaan administrasi perpajakan. Wajib pajak yang merasa tidak adil ketika membayar pajak dengan besaran yang tidak sesuai dengan kemampuannya cenderung mempengaruhi perilaku kepatuhan wajib pajak tersebut. Siahaan (2012) menyatakan bahwa kepatuhan sukarela wajib pajak dipengaruhi secara positif oleh keadilan pajak terutama dalam hal kemampuan wajib pajak untuk membayar pajak. Hal ini diperkuat oleh Sariani et al. (2016) dan Mustafa et al. (2016) yang menyatakan bahwa asas keadilan berpengaruh terhadap kepatuhan wajib pajak. Hasil penelitian berbeda dikemukakan oleh Suhartini (2015) bahwa penerapan sistem asas keadilan perpajakan tidak berpengaruh terhadap kepatuhan wajib pajak. Dengan demikian, dapat dikatakan bahwa penerapan asas keadilan perpajakan dapat berpengaruh maupun tidak berpengaruh terhadap kepatuhan wajib pajak.

Faktor lain yang mempengaruhi peningkatan kepatuhan wajib pajak adalah pelaksanaan sosialisasi perpajakan kepada wajib pajak. Seiring dengan perkembangan zaman dan teknologi, maka berdampak dengan perubahan pada beberapa peraturan dalam bidang perpajakan, termasuk kebijakan yang berlaku dalam Peraturan Pemerintah Nomor 23 Tahun 2018. Dengan adanya pelaksanaan sosialisasi perpajakan, maka wajib pajak 
dapat memahami peraturan dan kebijakan yang diatur dalam Peraturan Pemerintah Nomor 23 Tahun 2018 tersebut. Perubahan kebijakan-kebijakan yang telah dirumuskan oleh pemerintah dalam Peraturan Pemerintah Nomor 23 Tahun 2018 tersebut, tidak akan terlaksana dengan baik jika informasi tersebut tidak dipahami oleh wajib pajak. Menurut Ananda et al. (2015), sosialisasi perpajakan menjadi salah faktor yang tidak dapat dipisahkan dalam peningkatan kepatuhan wajib pajak. Rendahnya pelaksanaan sosialisasi perpajakan yang diberikan kepada wajib pajak berdampak terhadap rendahnya kepatuhan wajib pajak. Anwar dan Syafiqurrahman (2016) menyatakan bahwa persepsi wajib pajak yang menilai pajak hanyalah sebagai pungutan wajib tanpa melihat adanya manfaat dari pajak tersebut. Oleh karena itu, fungsi sosialisasi perpajakan sangat penting dalam merubah persepsi masyarakat terhadap perpajakan. Wardani dan Wati (2018) menyatakan bahwa kepatuhan wajib pajak dipengaruhi secara signifikan oleh sosialisasi perpajakan. Hal ini diperkuat oleh Ardy dan Damayanti (2018) serta Muhamad et al. (2019) yang menyatakan bahwa pelaksanaan sosialisasi perpajakan berpengaruh terhadap peningkatan kepatuhan wajib pajak. Hasil penelitian berbeda dikemukakan oleh
Warouw et al. (2015) bahwa kepatuhan wajib pajak tidak dipengaruhi oleh sosialisasi perpajakan. Dengan demikian, dapat dikatakan bahwa pelaksanaan sosialisasi perpajakan dapat berpengaruh maupun tidak berpengaruh terhadap kepatuhan wajib pajak.

Beberapa penelitian terdahulu meneliti mengenai pengaruh perubahan tarif pajak, penerapan asas keadilan perpajakan dan pelaksanaan sosialisasi perpajakan terhadap kepatuhan wajib pajak. Hasil dari penelitian terdahulu tersebut beberapa menyatakan bahwa tarif pajak, asas keadilan perpajakan dan sosialisasi perpajakan berpengaruh terhadap kepatuhan wajib pajak. Namun terdapat juga penelitian sebelumnya yang menyatakan bahwa tarif pajak, asas keadilan perpajakan dan sosialisasi perpajakan tidak berpengaruh terhadap kepatuhan wajib pajak. Hal ini disebabkan karena perbedaan lokus penelitian serta waktu pelaksanaan penelitian. Berdasarkan permasalahan tersebut, penelitian ini mengambil Kantor Pelayanan Pajak Pratama Bulukumba sebagai lokus penelitian.

Kantor Pelayanan Pajak Pratama Bulukumba adalah salah satu unit kerja Direktorat Jenderal Pajak Kementerian Keuangan Republik Indonesia yang melaksanakan fungsi pengadministrasian 
perpajakan. Kantor Pelayanan Pajak Pratama Bulukumba berada langsung di bawah Kantor Wilayah Direktorat Jenderal Pajak Sulawesi Selatan, Barat dan Tenggara dan memiliki cakupan wilayah kerja yaitu Kabupaten Bulukumba, Kabupaten Sinjai dan Kabupaten Kepulauan Selayar. Penerimaan pajak pada Kantor Pelayanan Pajak Pratama Bulukumba akan meningkat jika kepatuhan wajib pajak, termasuk wajib pajak Usaha, Mikro, Kecil dan Menengah (UMKM) yang berada di wilayah kerja Kantor Pelayanan Pajak Pratama Bulukumba juga meningkat.

Tujuan penelitian yang diajukan berdasarkan latar belakang permasalahan yaitu untuk mengetahui pengaruh perubahan tarif pajak terhadap kepatuhan wajib pajak, untuk mengetahui pengaruh penerapan asas keadilan perpajakan terhadap kepatuhan wajib pajak, untuk mengetahui pengaruh pelaksanaan sosialisasi perpajakan terhadap kepatuhan wajib pajak, serta untuk mengetahui pengaruh perubahan tarif, penerapan asas keadilan perpajakan dan pelaksanaan sosialisasi perpajakan atas penerapan Peraturan Pemerintah Nomor 23 Tahun 2018 secara simultan terhadap kepatuhan wajib pajak pada Kantor Pelayanan Pajak Pratama Bulukumba pasca berlakunya peraturan tersebut.
Hipotesis dalam penelitian ini mengenai pengaruh perubahan tarif, penerapan asas keadilan perpajakan dan pelaksanaan sosialisasi perpajakan terhadap kepatuhan wajib pajak. Hipotesis $1\left(\mathrm{H}_{1}\right)$ yaitu terdapat pengaruh yang signifikan antara perubahan tarif pajak secara parsial terhadap kepatuhan wajib pajak. Hipotesis $2\left(\mathrm{H}_{2}\right)$ yaitu terdapat pengaruh yang signifikan antara penerapan asas keadilan perpajakan secara parsial terhadap kepatuhan wajib pajak. Hipotesis $3\left(\mathrm{H}_{3}\right)$ yaitu terdapat pengaruh yang signifikan antara pelaksanaan sosialisasi perpajakan secara parsial terhadap kepatuhan wajib pajak. Hipotesis $4\left(\mathrm{H}_{4}\right)$ yaitu terdapat pengaruh yang signifikan antara perubahan tarif pajak, penerapan asas keadilan perpajakan dan pelaksanaan sosialisasi perpajakan secara simultan terhadap kepatuhan wajib pajak.

\section{METODE PENELITIAN}

Penelitian ini menggunakan metode kuantitatif melalui pendekatan penelitian eksplanatori, yaitu suatu metode penelitian yang digunakan untuk mengetahui hubungan kausal antara variabel-variabel melalui pengujian hipotesis.

Populasi dalam penelitian ini adalah wajib pajak yang terdaftar pada Kantor Pelayanan Pajak Pratama Bulukumba sebanyak 11.736 wajib pajak. Jumlah sampel dalam penelitian ditentukan 
menggunakan tabel Yount. Menurut Arikunto (2002), untuk populasi dengan jumlah di atas 10.000, maka besarnya sampel berdasarkan tabel Yount adalah minimal $1 \%$ dari jumlah populasi. Berdasarkan perhitungan tersebut, maka jumlah sampel yang dijadikan sebagai responden dalam penelitian ini sebanyak 120 wajib pajak. Penentuan sampel menggunakan teknik cluster random sampling, yaitu dengan mengambil secara acak wajib pajak badan dan orang pribadi usahawan yang memiliki peredaran usaha di bawah 4,8 miliar rupiah sebagai responden.

Penelitian ini menggunakan instrumen kuesioner sebagai metode pengumpulan data. Pengumpulan data dilakukan dengan menyebarkan kuesioner dengan daftar pernyataan tertutup yang diberikan kepada responden. Periode waktu pengumpulan data dalam penelitian ini dilakukan dengan cross section yang berlangsung selama bulan Januari tahun 2020.

Variabel-variabel yang digunakan penelitian adalah variabel bebas dan variabel terikat, yaitu tarif pajak (variabel $\mathrm{X}_{1}$ ), asas keadilan perpajakan (variabel $\mathrm{X}_{2}$ ) dan sosialisasi perpajakan (variabel $\mathrm{X}_{3}$ ) sebagai variabel bebas, serta kepatuhan wajib pajak (variabel Y) sebagai variabel terikat.
Masing-masing indikator dari setiap variabel dalam penelitian ini dituangkan dalam pertanyaan atau pernyataan. Setiap pertanyaan atau pernyataan untuk setiap variabel diukur menggunakan skala likert dengan nilai skor dari yang terendah hingga tertinggi secara berturut-turut diberikan nilai $1,2,3,4,5$ yang masingmasing memiliki makna sangat tidak setuju, tidak setuju, ragu-ragu, setuju, sangat setuju.

Pengujian kualitas instrumen masing-masing variabel bebas dan variabel terikat dalam penelitian ini menggunakan uji validitas dan uji realibilitas.

Metode yang digunakan untuk melakukan analisa data dalam penelitian ini menggunakan metode regresi. Adapun persamaan regresi tersebut sebagai berikut: $\mathrm{Y}=a+b \mathrm{X} 1+c \mathrm{X} 2+d \mathrm{X} 3$

dengan $a$ adalah konstanta, $b$ adalah koefisien regresi dari variabel $\mathrm{X}_{1}, c$ adalah koefisien regresi dari variabel $\mathrm{X}_{2}$ dan $d$ adalah koefiaen regresi dari variabel $\mathrm{X}_{3}$.

Untuk menghindari terjadinya beberapa masalah asumsi klasik dalam model regresi, maka perlu dilakukan uji asumsi klasik. Uji asumsi klasik diperlukan untuk memastikan bahwa model persamaan regresi yang didapatkan sudah tepat dalam mengestimasi serta konsisten dan tidak bias. Adapun uji asumsi klasik yang digunakan dalam 
penelitian ini yaitu menggunakan uji normalitas dengan menggunakan $p p$ plot dan nilai kolmogorov-smirnov $z$, uji multikolinieritas dengan menggunakan nilai tolerance dan VIF, uji autokorelasi dengan menggunakan nilai runs test dan uji heteroskedastisitas dengan menggunakan scatterplot dan nilai sig.

$$
\text { Untuk menguji pengaruh }
$$

perubahan tarif, penerapan asas keadilan perpajakan dan pelaksanaan sosialisasi perpajakan atas penerapan Peraturan Pemerintah Nomor 23 Tahun 2018 terhadap kepatuhan wajib pajak, digunakan analisis regresi linier berganda. Untuk menguji hipotesis dalam dalam penelitian ini, maka digunakan uji parsial dengan uji $\mathrm{t}$, uji simultan dengan uji $\mathrm{F}$ dan uji koefisien determinasi dengan koefisien determinasi $\left(\mathrm{R}^{2}\right)$.

\section{HASIL PENELITIAN}

Kepatuhan wajib pajak merupakan salah satu faktor yang mempengaruhi pencapaian penerimaan pajak. Kebijakan perpajakan dalam Peraturan Pemerintah Nomor 23 Tahun 2018 merupakan salah satu kebijakan yang memberikan kemudahan kepada wajib pajak yang berkaitan dengan pajak penghasilan. Adapun capaian realisasi penerimaan pajak penghasilan Kantor Pelayanan Pajak Pratama Bulukumba untuk tahun 2019 beserta pertumbuhannya dapat dilihat pada tabel berikut:

Tabel 1. Data Realisasi Pencapaian Penerimaan Pajak Penghasilan Kantor Pelayanan Pajak Pratama Bulukumba Tahun 2018 - 2019 (dalam Miliar Rupiah)

\begin{tabular}{ccccc}
\hline & & \multicolumn{2}{c}{ Realisasi } \\
\cline { 3 - 5 } Uraian & $\begin{array}{c}\text { Target } \\
\text { APBN } \\
2019\end{array}$ & 2018 & 2019 & $\begin{array}{c}\text { Pertum- } \\
\text { buhan (T) }\end{array}$ \\
\hline & & & & $\begin{array}{c}\text { Penca- } \\
\text { paian (C) }\end{array}$ \\
\hline
\end{tabular}

T: $\mathbf{7 , 7 3 \%}$

\section{\begin{tabular}{lllll} 
Jumlah & 168,82 & 134,79 & 145,21 & \\
\cline { 4 - 4 } & &
\end{tabular}}

Sumber: Data diolah dari Direktorat Jenderal Pajak (2020)

Berdasarkan tabel 1 diperoleh bahwa penerimaan pajak penghasilan Kantor Pelayanan Pajak Pratama Bulukumba pada tahun 2019 mencapai 145,21 miliar rupiah, atau 86,01\% dari target APBN 2019 sebesar 168,82 miliar rupiah dan mengalami pertumbuhan $7,73 \%$ dari penerimaan pajak penghasilan tahun 2018 yaitu 134,79 miliar rupiah. Berdasarkan informasi tersebut, dapat dikatakan bahwa realisasi penerimaan pajak penghasilan Kantor Pelayanan Pajak Pratama Bulukumba pada tahun 2019 tidak mencapai target penerimaan pajak penghasilan yang telah ditetapkan dalam APBN 2019, namun realisasi penerimaan pajak penghasilan tersebut masih lebih besar dari realisasi penerimaan pajak penghasilan pada tahun 2018 . 
Gambaran karakteristik variabelvariabel dalam penelitian dapat dilihat dalam tabel berikut:

Tabel 2. Hasil Uji Statistik Deskriftif

\begin{tabular}{cccccc}
\hline $\begin{array}{c}\text { Vari- } \\
\text { abel }\end{array}$ & N & Min & Max & Mean & $\begin{array}{c}\text { Std. } \\
\text { De viasi }\end{array}$ \\
\hline X1 & 120 & 17 & 25 & 21,11 & 2,473 \\
\hline X2 & 120 & 12 & 25 & 18,39 & 4,289 \\
\hline X3 & 120 & 12 & 25 & 19,10 & 3,789 \\
\hline Y & 120 & 20 & 25 & 23,55 & 1,460 \\
\hline
\end{tabular}

Sumber: Hasil Pengolahan Data 2020

Tabel 2 menunjukkan bahwa variabel tarif pajak $\left(X_{1}\right)$ memiliki nilai minimum sebesar 17 dan nilai maksimum sebesar 25, sedangkan nilai rata-rata atau mean sebesar 21,11 dan standar deviasi sebesar 2,473. Hal ini menunjukkan bahwa nilai variabel tarif pajak yang diteliti dengan nilai rata-ratanya terjadi perbedaan sebesar 2,473. Variabel asas keadilan perpajakan $\left(\mathrm{X}_{2}\right)$ memiliki nilai minimum sebesar 12 dan nilai maksimum sebesar 25 , sedangkan nilai rata-rata atau mean sebesar 28,39 dan standar deviasi sebesar 4,289. Hal ini menunjukkan bahwa nilai variabel asas keadilan perpajakan yang diteliti dengan nilai rata-ratanya terjadi perbedaan sebesar 4,289. Variabel sosialisasi perpajakan $\left(\mathrm{X}_{3}\right)$ memiliki nilai minimum sebesar 12 dan nilai maksimum sebesar 25, sedangkan nilai rata-rata atau mean sebesar 19,10 dan standar deviasi sebesar 3,789.

Hal ini menunjukkan bahwa nilai variabel sosialisasi perpajakan yang diteliti dengan nilai rata-ratanya terjadi perbedaan sebesar 3,789. Variabel kepatuhan wajib pajak (Y) memiliki nilai minimum sebesar 20 dan nilai maksimum sebesar 25, sedangkan nilai rata-rata atau meafatawn sebesar 23,55 dan standar deviasi sebesar 1,460. Hal ini menunjukkan bahwa nilai variabel kepatuhan wajib pajak yang diteliti dengan nilai rata-ratanya terjadi perbedaan sebesar 1,460.

Berdasarkan uji validitas terhadap variabel bebas, diperoleh hasil sebagai berikut:

Tabel 3. Hasil Uji Validitas Variabel Tarif Pajak

\begin{tabular}{|c|c|c|c|}
\hline $\begin{array}{c}\text { Item } \\
\text { Pertanyaa } \\
n\end{array}$ & $\begin{array}{c}\text { Nilai } \\
\text { Pearson } \\
\text { Correlatio } \\
n\end{array}$ & $\begin{array}{l}\text { Nilai } \\
\mathbf{r} \\
\text { tabel }\end{array}$ & $\begin{array}{l}\text { Kesim } \\
\text {-pulan }\end{array}$ \\
\hline X1.1 & 0,705 & $\begin{array}{c}0,17 \\
9\end{array}$ & Valid \\
\hline $\mathrm{X} 1.2$ & 0,662 & $\begin{array}{c}0,17 \\
9\end{array}$ & Valid \\
\hline $\mathrm{X} 1.3$ & 0,734 & $\begin{array}{c}0,17 \\
9\end{array}$ & Valid \\
\hline X1.4 & 0,743 & $\begin{array}{c}0,17 \\
9\end{array}$ & Valid \\
\hline X1.5 & 0,572 & $\begin{array}{c}0,17 \\
9\end{array}$ & Valid \\
\hline $\begin{array}{r}\text { Sumber: } \\
\text { Tabel 4. Ha } \\
\text { Asas Keadi }\end{array}$ & $\begin{array}{l}\text { asil Pengolal } \\
\text { il Uji Validi } \\
\text { an Perpajak }\end{array}$ & an Data & 2020 \\
\hline $\begin{array}{c}\text { Item } \\
\text { Pertanyaa } \\
n\end{array}$ & $\begin{array}{c}\text { Nilai } \\
\text { Pearson } \\
\text { Correlatio } \\
n\end{array}$ & $\begin{array}{l}\text { Nilai } \\
\mathbf{r} \\
\text { tabel }\end{array}$ & $\begin{array}{l}\text { Kesim } \\
\text {-pulan }\end{array}$ \\
\hline X2.1 & 0,813 & $\begin{array}{c}0,17 \\
9\end{array}$ & Valid \\
\hline X2.2 & 0,860 & $\begin{array}{c}0,17 \\
9\end{array}$ & Valid \\
\hline X2.3 & 0,898 & 0,17 & Valid \\
\hline
\end{tabular}




\begin{tabular}{cccc}
\hline X2.4 & \multicolumn{3}{c}{9} \\
\hline $\mathbf{X 2 . 5}$ & 0,891 & $\begin{array}{c}0,17 \\
9\end{array}$ & Valid \\
& 0,835 & $\begin{array}{c}0,17 \\
9\end{array}$ & Valid \\
\hline
\end{tabular}

Sumber: Hasil Pengolahan Data 2020

Tabel 5. Hasil Uji Validitas Variabel Sosialisasi Perpajakan

\begin{tabular}{cccc}
$\begin{array}{c}\text { Item } \\
\text { Pertanyaa } \\
\mathbf{n}\end{array}$ & $\begin{array}{c}\text { Nilai } \\
\text { Pearson } \\
\text { Correlatio } \\
\boldsymbol{n}\end{array}$ & $\begin{array}{c}\text { Nilai } \\
\mathbf{r} \\
\text { tabel }\end{array}$ & $\begin{array}{c}\text { Kesim } \\
\text {-pulan }\end{array}$ \\
\hline $\mathbf{X 3 . 1}$ & 0,809 & $\begin{array}{c}0,17 \\
9\end{array}$ & Valid \\
\hline $\mathbf{X 3 . 2}$ & 0,890 & $\begin{array}{c}0,17 \\
9\end{array}$ & Valid \\
\hline $\mathbf{X 3 . 3}$ & 0,841 & $\begin{array}{c}0,17 \\
9\end{array}$ & Valid \\
\hline $\mathbf{X 3 . 4}$ & 0,853 & $\begin{array}{c}0,17 \\
9\end{array}$ & Valid \\
\hline $\mathbf{X 3 . 5}$ & 0,764 & $\begin{array}{c}0,17 \\
9\end{array}$ & Valid \\
\hline
\end{tabular}

Sumber: Hasil Pengolahan Data 2020

Berdasarkan tabel 3, tabel 4 dan tabel 5, diperoleh gambaran bahwa uji instrumen untuk variabel bebas, yaitu tarif pajak $\left(\mathrm{X}_{1}\right)$, asas keadilan perpajakan $\left(\mathrm{X}_{2}\right)$ dan sosialisasi perpajakan $\left(\mathrm{X}_{3}\right)$ menunjukkan bahwa nilai pearson correlation untuk masing-masing item pertanyaan lebih besar dari nilai r-tabel yaitu 0,179, sehingga bisa disimpulkan bahwa semua pertanyaan yang digunakan sebagai instrumen untuk variabel bebas adalah valid.

Berdasarkan uji validitas terhadap variabel terikat, diperoleh hasil sebagai berikut:
Tabel 6. Hasil Uji Validitas Variabel Kepatuhan Wajib Pajak

\begin{tabular}{cccc}
$\begin{array}{c}\text { Item } \\
\text { Pertanyaa } \\
\mathbf{n}\end{array}$ & $\begin{array}{c}\text { Nilai } \\
\text { Pearson } \\
\text { Correlatio } \\
\boldsymbol{n}\end{array}$ & $\begin{array}{c}\text { Nilai } \\
\mathbf{r} \\
\text { tabel }\end{array}$ & $\begin{array}{c}\text { Kesim } \\
\text {-pulan }\end{array}$ \\
\hline Y.1 & 0,324 & $\begin{array}{c}0,17 \\
9\end{array}$ & Valid \\
\hline Y.2 & 0,252 & $\begin{array}{c}0,17 \\
9\end{array}$ & Valid \\
\hline Y.3 & 0,392 & 0,17 & Valid \\
& & 9 & \\
\hline Y.4 & 0,329 & 0,17 & Valid \\
& & 9 & \\
\hline Y.5 & 0,474 & 0,17 & Valid \\
& & 9 & \\
\hline Y.6 & 0,352 & 0,17 & Valid \\
& & 9 & \\
\hline Sumber: Hasil Pengolahan Data & 2020
\end{tabular}

Berdasarkan tabel 6 diperoleh gambaran bahwa uji instrumen untuk variabel terikat, yaitu kepatuhan wajib pajak (Y) menunjukkan bahwa nilai pearson correlation untuk masing-masing butir pernyataan lebih besar dari nilai $\mathrm{r}$ tabel yaitu 0,179 , sehingga bisa disimpulkan bahwa semua pertanyaan yang digunakan sebagai instrumen untuk variabel terikat adalah valid.

Uji reliabilitas yang dilakukan terhadap variabel bebas dan variabel terikat diperoleh hasil sebagai berikut:

Tabel 7. Hasil Uji Realibiltas

\begin{tabular}{lccc}
\hline Variabel & $\begin{array}{c}\text { Nilai } \\
\text { Cronbach's } \\
\text { Alpha }\end{array}$ & $\begin{array}{c}\text { Nilai } \\
\text { Batas } \\
\text { Alpha }\end{array}$ & $\begin{array}{c}\text { Kesim- } \\
\text { pulan }\end{array}$ \\
\hline Tarif Pajak & 0,713 & 0,6 & Reliabel \\
\hline $\begin{array}{l}\text { Asas } \\
\text { Keadilan } \\
\text { Perpajakan }\end{array}$ & 0,914 & 0,6 & Reliabel \\
\hline $\begin{array}{l}\text { Sosialisasi } \\
\text { Perpajakan }\end{array}$ & 0,889 & 0,6 & Reliabel \\
\hline
\end{tabular}




\begin{tabular}{llll}
\hline $\begin{array}{l}\text { Kepatuhan } \\
\text { Wajib }\end{array}$ & 0,686 & 0,6 & Reliabel \\
Pajak & & & \\
\hline
\end{tabular}

Sumber: Hasil Pengolahan Data 2020

Hasil pengujian reabilitas dari masing-masing variabel sebagaiamana terlihat pada tabel 7 menunjukkan bahwa nilai cronbach's alpha untuk masingmasing variabel bebas maupun variabel terikat lebih besar dari nilai batas alpha yaitu 0,6 , sehingga bisa disimpulkan bahwa seluruh instrumen yang digunakan untuk mengukur seluruh item dari variabel bebas yaitu tarif pajak $\left(\mathrm{X}_{1}\right)$, asas keadilan perpajakan $\left(\mathrm{X}_{2}\right)$ dan sosialisasi perpajakan $\left(\mathrm{X}_{3}\right)$ serta variabel terikat yaitu kepatuhan wajib pajak (Y) dinyatakan reliabel.

Hasil dari uji normalitas diperoleh sebagai berikut:

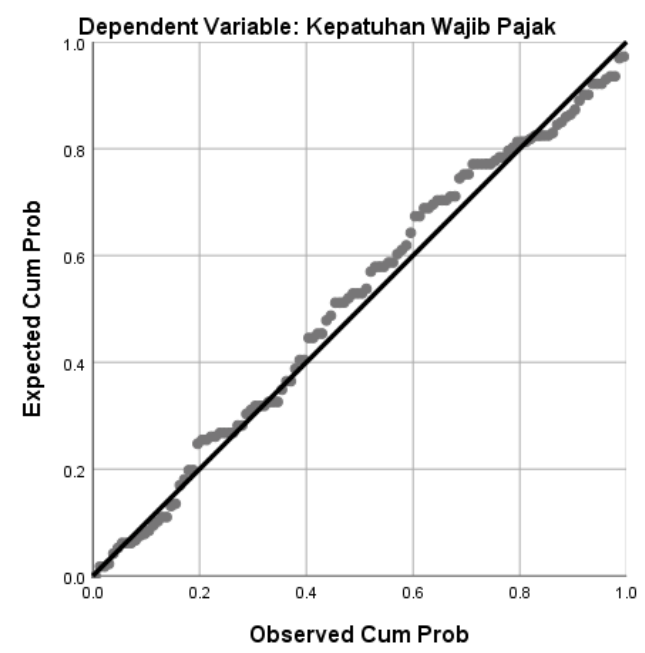

Sumber: Hasil Pengolahan Data 2020

\section{Gambar 1. PP Plots Hasil Uji Normalitas}

Gambar 1 menunjukkan bahwa sebaran data berada di sekitar garis

diagonal sebagai representasi pola distribusi normal. Hal ini berarti bahwa model regresi memenuhi asumsi uji normalitas. Selain itu juga bisa ditunjukkan dari nilai kolmogorov-smirnov $z$, sebagai berikut:

\section{Tabel 8. Hasil Uji Normalitas}

\begin{tabular}{cccc}
\hline $\begin{array}{c}\text { Mode } \\
\text { I }\end{array}$ & $\begin{array}{c}\text { Kolmogorov } \\
\text {-Smirnov Z }\end{array}$ & $\begin{array}{c}\text { Asymp.Si } \\
\text { g (2- } \\
\text { tailed) }\end{array}$ & $\begin{array}{c}\text { Alph } \\
\text { a }\end{array}$ \\
\hline $\mathbf{1}$ & 0,076 & 0,089 & 0,05 \\
\hline \multicolumn{4}{c}{ Sumber: Hasil Pengolahan Data 2020 } \\
\multicolumn{4}{r}{ Berdasarkan tabel 8, diperoleh }
\end{tabular}
bahwa nilai kolmogorov-smirnov $z$ sebesar 0,076 dan nilai asymp.sig sebesar 0,089. Dari hasil tersebut diperoleh bahwa nilai asymp.sig lebih besar dari alpha yaitu 0,089 lebih besar dari 0,05. Hal ini berarti bahwa model regresi berdistribusi normal. Baik menggunakan hasil PP Plots maupun nilai kolmogorov-smirnov $z$, diperoleh bahwa model regresi dalam penelitian ini berdistribusi normal.

Hasil uji multikolinieritas diperoleh sebagai berikut:

Tabel 9. Hasil Uji Multikolinie ritas

\begin{tabular}{lcc}
\hline \multicolumn{1}{c}{ Variabel } & Tolerance & VIF \\
\hline Tarif Pajak & 0,989 & 1,011 \\
\hline $\begin{array}{l}\text { Asas Keadilan } \\
\text { Perpajakan }\end{array}$ & 0,991 & 1,009 \\
\hline $\begin{array}{l}\text { Sosialisasi } \\
\text { Perpajakan }\end{array}$ & 0,995 & 1,005 \\
\hline \multicolumn{2}{c}{ Sumber: Hasil Pengolahan Data 2020 } \\
\multicolumn{2}{c}{ Berdasarkan tabel } & $9, \quad$ diperoleh \\
bahwa nilai VIF & untuk masing-masing
\end{tabular}


variabel bebas lebih kecil dari 10 dan nilai tolerance untuk masing-masing variabel bebas lebih besar dari 0,1 . Karena nilai VIF lebih kecil dari 10 dan nilai tolerance lebih besar dari 0,1 , dapat dikatakan bahwa antara variabel bebas dalam penelitian ini tidak terjadi hubungan atau tidak memiliki hubungan antara satu dengan yang lainnya. Hal ini berarti bahwa gejala multikolinieritas antar variabel bebas dalam model regresi tidak terjadi pada penelitian ini.

Hasil uji autokorelasi diperoleh sebagai berikut:

\section{Tabel 10. Hasil Uji Autokorelasi}

\begin{tabular}{cccc}
\hline Model & $\begin{array}{c}\text { Runs } \\
\text { Test }\end{array}$ & $\begin{array}{c}\text { Asymp.Sig } \\
\text { (2-tailed) }\end{array}$ & Alpha \\
\hline $\mathbf{1}$ & 0.183 & 0.855 & 0,05 \\
\hline Sumber: & Hasil Pengolahan Data 2020
\end{tabular}

Berdasarkan tabel 10, diperoleh bahwa nilai runs test sebesar 0,183 dan nilai asymp.sig sebesar 0,855. Dari hasil tersebut diperoleh bahwa nilai asymp.sig yaitu 0,855 lebih besar dari alpha yaitu 0,05. Dengan demikian, dapat disimpulkan bahwa tidak terjadi autokorelasi pada model regresi dalam penelitian ini. Dengan kata lain, dapat dikatakan bahwa antara sampel yang satu dengan sampel yang lainnya tidak saling berkorelasi.

Hasil uji heteroskedastisitas diperoleh sebagai berikut:

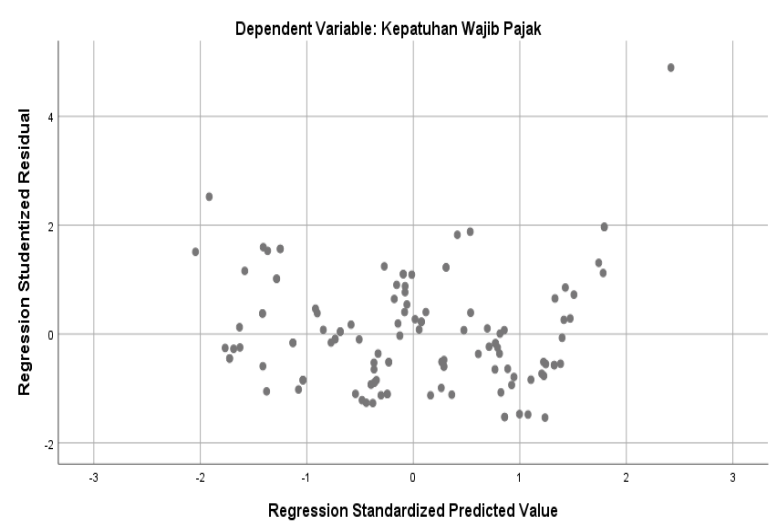

Sumber: Hasil Pengolahan Data 2020

\section{Gambar 2. Scatterplot Hasil Uji} Heteroskedastisitas

Gambar 2 menunjukkan bahwa sebaran data tidak beraturan dan tidak membentuk pola tertentu. Hal ini berarti bahwa tidak terjadi gejala heteroskedastisitas dalam model regresi. Selain itu juga bisa dilihat dari perbandingan nilai koefisien dengan nilai sig sebagai berikut:

Tabel 11. Hasil Uji Heteroskedastisitas

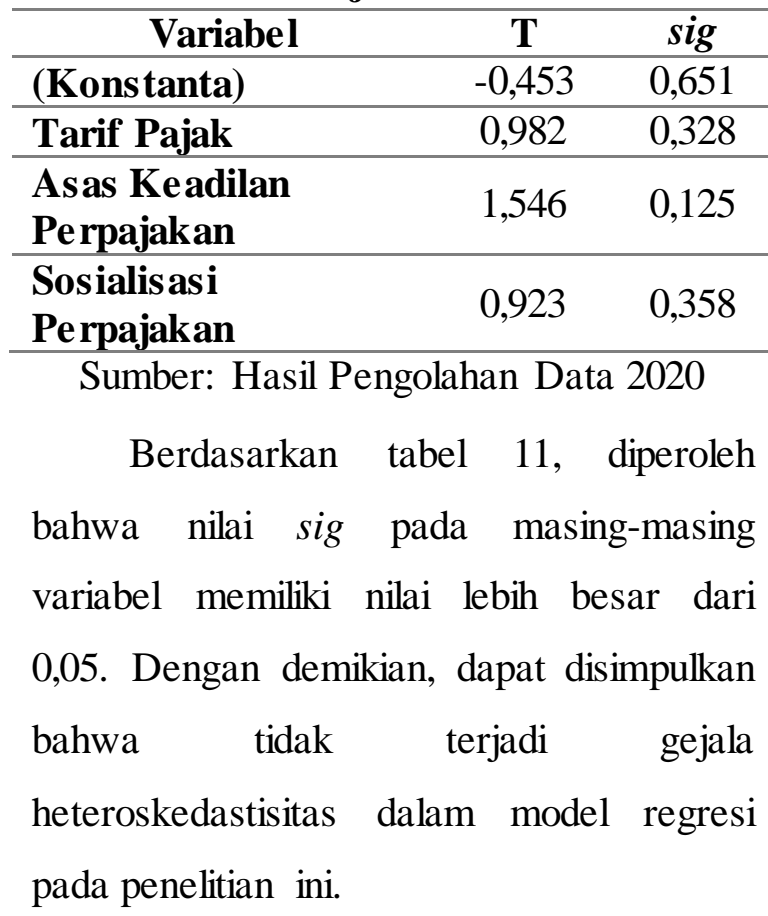


Model regresi dalam penelitian ini memenuhi seluruh kriteria uji asumsi klasik, sehingga bisa dilanjutkan ke uji regresi linier berganda.

Hasil uji regresi linier berganda terhadap ketiga variabel bebas, yaitu tarif pajak $\left(\mathrm{X}_{1}\right)$, asas keadilan perpajakan $\left(\mathrm{X}_{2}\right)$ dan sosialisasi perpajakan $\left(\mathrm{X}_{3}\right)$ dapat dilihat pada tabel berikut:

Tabel 12. Hasil Pengujian Regresi Linier Berganda

\begin{tabular}{|c|c|c|c|}
\hline \multirow[t]{2}{*}{ Variabel } & \multirow[t]{2}{*}{ B } & \multicolumn{2}{|c|}{ Uji t } \\
\hline & & $\begin{array}{c}\mathrm{t} \\
\text { hitung }\end{array}$ & sig \\
\hline (Konstanta) & 10,647 & 22,915 & 0,000 \\
\hline Tarif Pajak & 0,296 & 16,312 & 0,000 \\
\hline $\begin{array}{l}\text { Asas Keadilan } \\
\text { Perpajakan }\end{array}$ & 0,235 & 22,467 & 0,000 \\
\hline \multirow[t]{4}{*}{$\begin{array}{l}\text { Sosialis asi } \\
\text { Perpajakan }\end{array}$} & 0,122 & 10,370 & 0,000 \\
\hline & \multicolumn{2}{|c|}{ Uji F } & $\mathbf{R}^{2}$ \\
\hline & $\begin{array}{c}\mathbf{F} \\
\text { hitung }\end{array}$ & sig & \\
\hline & 318,371 & 0,000 & 0,892 \\
\hline
\end{tabular}

Sumber: Hasil Pengolahan Data 2020

Tabel 12 menunjukkan nilai koefisien determinasi $\left(\mathrm{R}^{2}\right)$ sebesar 0,892, yang berarti bahwa ada pengaruh sebesar 0,892 atau $89,2 \%$ dari variabel bebas, yaitu tarif pajak $\left(\mathrm{X}_{1}\right)$, asas keadilan perpajakan $\left(\mathrm{X}_{2}\right)$ dan sosialisasi perpajakan $\left(\mathrm{X}_{3}\right)$ dalam menjelaskan variabel terikat yaitu kepatuhan wajib pajak (Y), sedangkan sisanya sebesar 0,108 atau $10,8 \%$ dijelaskan oleh variabel lainnya yang tidak diteliti dalam model penelitian ini.
Persamaan regresi linier berganda untuk penelitian ini diperoleh berdasarkan hasil pengujian regresi linier pada tabel 12 sebagai berikut:

\section{$Y=10,647+0,296 X 1+0,235 X 2+$ $0,122 \times 3$}

Berdasarkan persamaan regresi tersebut, diperoleh bahwa semua variabel bebas berpengaruh positif terhadap variabel terikat. Hal ini terlihat dari nilai koefisien regresi untuk variabel tarif pajak $\left(\mathrm{X}_{1}\right)$, asas keadilan perpajakan $\left(\mathrm{X}_{2}\right)$ dan sosialisasi perpajakan $\left(\mathrm{X}_{3}\right)$ pada persamaan regresi tersebut semuanya positif. Nilai konstanta sebesar 10,647 dapat diartikan bahwa nilai kepatuhan wajib pajak (Y) cenderung meningkat sebesar 10,647 apabila nilai tarif pajak $\left(\mathrm{X}_{1}\right)$, asas keadilan perpajakan $\left(\mathrm{X}_{2}\right)$ dan sosialisasi perpajakan $\left(\mathrm{X}_{3}\right)$ sama dengan nol. Nilai koefisien dari $\mathrm{X}_{1}$ sebesar 0,296 dapat diartikan bahwa nilai kepatuhan wajib pajak (Y) cenderung meningkat sebesar 0,296 satuan apabilai nilai tarif pajak $\left(\mathrm{X}_{1}\right)$ meningkat satu satuan, sedangkan variabel bebas lainnya bernilai nol. Nilai koefisien dari $\mathrm{X}_{2}$ sebesar 0,235 dapat diartikan bahwa nilai kepatuhan wajib pajak (Y) cenderung meningkat sebesar 0,235 satuan apabila nilai asas keadilan perpajakan $\left(\mathrm{X}_{2}\right)$ meningkat satu satuan, sedangkan variabel bebas lainnya 
bernilai nol. Nilai koefisien dari $\mathrm{X}_{3}$ sebesar 0,122 dapat diartikan bahwa nilai kepatuhan wajib pajak (Y) cenderung meningkat sebesar 0,122 satuan apabila nilai sosialisasi perpajakan $\left(\mathrm{X}_{3}\right)$ meningkat satu satuan, sedangkan variabel bebas lainnya bernilai nol.

Hasil pengujian hipotesis secara parsial diperoleh berdasarkan nilai koefisien regresi pada tabel 12. Nilai $\mathrm{t}$ hitung untuk variabel tarif pajak $\left(\mathrm{X}_{1}\right)$ dengan kepatuhan wajib pajak (Y) adalah sebesar 16,312 dengan angka sig sebesar 0,000. Berdasarkan informasi tersebut, diketahui bahwa angka sig lebih kecil dari alpha, yaitu 0,000 lebih kecil dari 0,05, hal ini berarti $\mathrm{H}_{1}$ diterima, sehingga dapat disimpulkan bahwa perubahan tarif pajak pada Peraturan Pemerintah Nomor 23 Tahun 2018 mempunyai pengaruh positif dan signifikan terhadap kepatuhan wajib pajak pada Kantor Pelayanan Pajak Pratama Bulukumba.

Nilai t-hitung untuk variabel asas keadilan perpajakan $\left(\mathrm{X}_{2}\right)$ dengan kepatuhan wajib pajak (Y) adalah sebesar 22,467 dengan angka sig sebesar 0,000. Berdasarkan informasi tersebut, diketahui bahwa angka sig lebih kecil dari alpha, yaitu 0,000 lebih kecil dari 0,05, hal ini berarti $\mathrm{H}_{2}$ diterima, sehingga dapat disimpulkan bahwa penerapan asas keadilan perpajakan pada Peraturan Pemerintah Nomor 23 Tahun 2018 mempunyai pengaruh positif dan signifikan terhadap kepatuhan wajib pajak pada Kantor Pelayanan Pajak Pratama Bulukumba.

Nilai t-hitung untuk variabel sosialisasi perpajakan $\left(\mathrm{X}_{3}\right)$ dengan kepatuhan wajib pajak (Y) adalah sebesar 10,370 dengan angka sig sebesar 0,000. Berdasarkan informasi tersebut, diketahui bahwa angka sig lebih kecil dari alpha, yaitu 0,000 lebih kecil dari 0,05, hal ini berarti $\mathrm{H}_{3}$ diterima, sehingga dapat disimpulkan bahwa pelaksanaan sosialisasi perpajakan pada Peraturan Pemerintah Nomor 23 Tahun 2018 mempunyai pengaruh positif dan signifikan terhadap kepatuhan wajib pajak pada Kantor Pelayanan Pajak Pratama Bulukumba.

Hasil pengujian hipotesis secara simultan berdasarkan informasi pada tabel 12, diperoleh bahwa nilai F-hitung sebesar 318,371 dengan angka sig sebesar 0,000. Karena angka sig lebih kecil dari alpha, yaitu 0,000 lebih kecil dari 0,05, hal ini berarti $\mathrm{H}_{4}$ diterima, sehingga dapat disimpulkan bahwa tarif pajak, asas keadilan perpajakan dan sosialisasi perpajakan pada Peraturan Pemerintah Nomor 23 Tahun 2018 secara simultan mempunyai pengaruh positif dan 
signifikan terhadap kepatuhan wajib pajak pada Kantor Pelayanan Pajak Pratama Bulukumba.

\section{PEMBAHASAN}

Penelitian ini bertujuan untuk mengetahui pengaruh perubahan tarif pajak secara parsial terhadap kepatuhan wajib pajak, pengaruh penerapan asas keadilan perpajakan secara parsial terhadap kepatuhan wajib pajak, pengaruh pelaksanaan sosialisasi perpajakan secara parsial terhadap kepatuhan wajib pajak, pengaruh perubahan tarif pajak, penerapan asas keadilan perpajakan dan pelaksanaan sosialisasi perpajakan atas penerapan Peraturan Pemerintah Nomor 23 Tahun 2018 secara simultan terhadap kepatuhan wajib pajak pada Kantor Pelayanan Pajak Pratama Bulukumba. Berdasarkan hasil penelitian, masing-masing tujuan penelitian dibahas sebagai berikut:

Pengaruh perubahan tarif pajak terhadap kepatuhan wajib pajak diperoleh dari hasil perhitungan koefisien regresi. Berdasarkan perhitungan analisis regresi, diperoleh bahwa koefisien regresi pada variabel tarif pajak $\left(\mathrm{X}_{1}\right)$ sebesar 0,296. Nilai koefisien regresi tersebut memiliki nilai positif terhadap variabel kepatuhan wajib pajak (Y). Dengan demikian, dapat dikatakan bahwa perubahan tarif pajak berpengaruh terhadap kepatuhan wajib pajak. Dengan kata lain juga dapat dikatakan bahwa adanya kebijakan pemerintah untuk menurunkan tarif pajak pada Peraturan Pemerintah Nomor 23 Tahun 2018 menjadi 0,5\%, memberikan pengaruh terhadap peningkatan kepatuhan wajib pajak.

Hasil penelitian ini sejalan dengan penelitian yang dikemukakan oleh Cahyani dan Noviari (2019) bahwa kepatuhan wajib pajak dipengaruhi secara positif dan signifikan oleh tarif pajak. Hasil penelitian ini tidak sejalan dengan penelitian yang dilakukan oleh Yusro dan Kiswanto (2014) pada Kantor Pelayanan Pajak di Kabupaten Jepara dan Mustofa et al. (2016) pada Kantor Pelayanan Pajak Pratama Batu, yang menyatakan bahwa tarif pajak tidak berpengaruh secara signifikan terhadap kepatuhan wajib pajak. Hasil Penelitian ini juga memperkuat dan mendukung penelitian yang dilakukan oleh Atawodi dan Ojeka (2012), Ananda et al. (2015), Tawas et al. (2016), Lazuardini et al. (2018) dan Muhamad et al. (2019) yang menunjukkan bahwa tarif pajak mempunyai pengaruh signifikan terhadap kepatuhan wajib pajak.

Pengaruh penerapan asas keadilan perpajakan terhadap kepatuhan wajib pajak diperoleh dari hasil perhitungan koefisien regresi. Berdasarkan perhitungan analisis regresi, diperoleh bahwa koefisien 
regresi pada variabel asas keadilan perpajakan $\left(\mathrm{X}_{2}\right)$ sebesar 0,235 . Nilai koefisien regresi tersebut memiliki nilai positif terhadap variabel kepatuhan wajib pajak (Y). Dengan demikian, dapat dikatakan bahwa semakin adilnya pengenaan pajak, maka akan semakin meningkatkan kepatuhan wajib pajak. Dengan kata lain juga dapat dikatakan bahwa adanya asas keadilan pada Peraturan Pemerintah Nomor 23 Tahun 2018, yaitu diberikannya pilihan kepada wajib pajak untuk memilih antara menggunakan tarif pajak penghasilan final $0,5 \%$ atau menggunakan tarif pajak penghasilan secara umum dengan menyelenggarakan pembukuan, memberikan pengaruh terhadap peningkatan kepatuhan wajib pajak.

Hasil penelitian ini sejalan dengan penelitian yang dikemukakan oleh Basri dan Surya (2014) bahwa kepatuhan wajib pajak dipengaruhi secara positif dan signifikan oleh asas keadilan perpajakan. Hasil penelitian ini tidak sejalan dengan penelitian yang dilakukan oleh Benk et al. (2011) dan Suhartini (2015) pada Kantor Pelayanan Pajak Madya Pekanbaru, yang menyatakan bahwa asas keadilan perpajakan tidak berpengaruh secara signifikan terhadap kepatuhan wajib pajak. Hasil Penelitian ini juga memperkuat dan mendukung penelitian yang dilakukan oleh
Hai dan See (2011), Siahaan (2012), Sari dan Mangoting (2014), Fadilah dan Panjaitan (2016) serta Sariani et al. (2016), yang menunjukkan bahwa asas keadilan perpajakan mempunyai pengaruh signifikan terhadap kepatuhan wajib pajak.

Pengaruh pelaksanaan sosialisasi perpajakan terhadap kepatuhan wajib pajak diperoleh dari hasil perhitungan koefisien regresi. Berdasarkan perhitungan analisis regresi, diperoleh bahwa koefisien regresi pada variabel sosialisasi perpajakan $\left(\mathrm{X}_{3}\right)$ sebesar 0,122 . Nilai koefisien regresi tersebut memiliki nilai positif terhadap variabel kepatuhan wajib pajak (Y). Dengan demikian, dapat dikatakan bahwa pelaksanaan sosialisasi perpajakan berpengaruh terhadap kepatuhan wajib pajak. Dengan kata lain juga dapat dikatakan bahwa semakin banyaknya sosialisasi perpajakan atas penerapan Peraturan Pemerintah Nomor 23 Tahun 2018 yang dilakukan oleh fiskus, maka akan semakin meningkatkan kepatuhan wajib pajak

Hasil penelitian ini sejalan dengan penelitian yang dikemukakan oleh Nababan dan Dwimulyani (2019) bahwa sosialisasi perpajakan berpengaruh positif dan signifikan terhadap kepatuhan wajib pajak. Hasil penelitian ini tidak sejalan dengan penelitian yang dilakukan oleh Winerungan (2013) pada Kantor 
Pelayanan Pajak Pratama Manado dan Kantor Pelayanan Pajak Pratama Bitung dan Adiatma et al. (2015) pada Kantor Pelayanan Pajak Pratama Malang Utara, yang menyatakan bahwa sosialisasi perpajakan tidak berpengaruh secara signifikan terhadap kepatuhan wajib pajak. Hasil Penelitian ini juga memperkuat dan mendukung penelitian yang dilakukan oleh Ananda et al. (2015), Puspita (2016), Anwar dan Syafiqurrahman (2016), Boediono et al. (2018), Banamtuan (2018), Ardy dan Damayanti (2018) serta Wardani dan Wati (2018) yang menunjukkan bahwa sosialisasi perpajakan mempunyai pengaruh signifikan terhadap kepatuhan wajib pajak.

Pengaruh perubahan tarif pajak, penerapan asas keadilan perpajakan dan pelaksanaan sosialisasi perpajakan secara simultan terhadap kepatuhan wajib pajak diperoleh dari hasil perhitungan koefisien determinasi $\left(\mathrm{R}^{2}\right)$. Berdasarkan perhitungan analisis regresi, diperoleh bahwa koefisien determinasi sebesar 0,892 atau 89,2\%. Nilai koefisien determinasi tersebut menunjukkan bahwa kepatuhan wajib pajak dipengaruhi secara positif oleh faktor tarif pajak, asas keadilan perpajakan dan sosialisasi perpajakan secara simultan sebesar 0,892 atau 89,2\%, sedangkan sisanya sebesar 0,108 atau $10,8 \%$ dijelaskan oleh variabel lain yang tidak diteliti dalam penelitian ini.

Hasil penelitian ini menunjukkan bahwa seiring dengan adanya perubahan tarif pajak, semakin adilnya pengenaan pajak, serta semakin tingginya pelaksanaan sosialisasi atas penerapan Peraturan Pemerintah Nomor 23 Tahun 2018, maka kepatuhan wajib pajak pada Kantor Pelayanan Pajak Pratama Bulukumba akan meningkat.

Penurunan tarif pajak penghasilan final menjadi $0,5 \%$ pada Peraturan Pemerintah Nomor 23 Tahun 2018 memberikan dampak positif terhadap kepatuhan wajib pajak. Jumlah pajak terutang yang harus dibayarkan oleh wajib pajak dengan jumlah peredaran bruto yang sama, menjadi lebih sedikit sehingga membantu mengurangi beban wajib pajak dalam membayar pajak. Dengan adanya kebijakan ini, wajib pajak diharapkan bisa memanfaatkan kesempatan ini dengan sebaik-baiknya. Wajib pajak diharapkan agar senantiasa tidak menyembunyikan jumlah peredaran brutonya dan sebaliknya membayarkan pajak sesuai dengan keadaan sebenarnya. Kebijakan dalam peraturan ini memberiksan ruang kepada wajib pajak yang merasa tidak memiliki kemampuan untuk menyetorkan pajak yang terutang dengan menggunakan tarif pajak penghasilan final $0,5 \%$, yang 
disebabkan karena wajib pajak mengalami kerugian secara fiskal atau jumlah keuntungan bersih yang diperoleh lebih kecil dibandingkan dengan proporsi jumlah peredaran brutonya. Wajib pajak tersebut dapat menyelenggarakan pembukuan dan menghitung jumlah pajak yang terutang dengan menggunakan tarif pajak penghasilan secara umum yang dikenakan terhadap keuntungan bersih wajib pajak. Wajib pajak bisa menggunakan fasilitas pilihan pembukuan ini dengan terlebih dahulu menyampaikan pemberitahuan tertulis ke Kantor Pelayanan Pajak. Dengan adanya kebijakan ini, maka pengenaan pajak kepada wajib pajak menjadi lebih adil karena jumlah pajak yang disetorkan sesuai dengan tingkat penghasilan dan kemampuan membayar dari masingmasing wajib pajak.

Sebagai pelaksanaan self assessment system, dimana wajib pajak menyetorkan sendiri pajak terutangnya sesuai dengan perhitungan wajib pajak, maka pihak fiskus pada Kantor Pelayanan Pajak Pratama Bulukumba agar selalu melakukan pengawasan kepada wajib pajak. Pengawasan tersebut sebagai sarana untuk menguji kepatuhan wajib pajak dalam melakukan penyetoran dan pelaporan pajak. Pengawasan juga diperlukan dalam rangka mengetahui apakah wajib pajak telah benar dalam melaksanakan penyetoran dan pelaporan pajak. Selain fungsi pengawasan, pihak fiskus pada Kantor Pelayanan Pajak Pratama Bulukumba juga diharapkan selalu meningkatkan pelaksanaan sosialisasi atas penerapan Peraturan Pemerintah Nomor 23 Tahun 2018. Sosialisasi perpajakan perlu dilaksanakan agar kebijakan perpajakan dalam peraturan tersebut dipahami oleh wajib pajak, sehingga wajib pajak bisa memanfaatkan fasilitas perpajakan yang diatur dalam peraturan tersebut dengan maksimal. Penggunaan tarif pajak penghasilan final 0,5\% dalam Peraturan Pemerintah Nomor 23 Tahun 2018 ini, tidak berlangsung selamanya, tetapi memiliki batasan waktu, yaitu 7 tahun untuk wajib pajak orang pribadi, 4 tahun untuk wajib pajak badan berbentuk koperasi, persekutuan komanditer dan firma, serta 3 tahun untuk wajib pajak badan berbentuk perseroan terbatas. Oleh karena itu, pendampingan fiskus kepada wajib pajak dalam penyelenggaraan pembukuan sangat diperlukan. Wajib pajak agar diberikan pendampingan dalam membuat pembukuan sederhana, sehingga ketika sudah sampai batas akhir untuk menggunakan tarif pajak penghasilan final $0,5 \%$ ini, wajib pajak sudah terbiasa dalam menyelenggarakan pembukuan. 
Dengan adanya kebijakan penurunan tarif menjadi $0,5 \%$ dan penerapan asas keadilan perpajakan dengan diberikannya pilihan kepada wajib pajak untuk memilih tarif pajak penghasilan final atau tarif pajak penghasilan secara umum dengan menyelenggarakan pembukuan, serta dengan semakin tingginya pelaksanaan sosialisasi atas penerapan Peraturan Pemerintah Nomor 23 Tahun 2013, diharapkan akan meningkatkan kepatuhan wajib pajak pada Kantor Pelayanan Pajak Pratama Bulukumba.

\section{KESIMPULAN DAN SARAN}

Berdasarkan hasil penelitian dan pembahasan diperoleh kesimpulan yaitu penurunan tarif pajak berpengaruh terhadap kepatuhan wajib pajak. Hal ini berarti bahwa pengujian hipotesis $1\left(\mathrm{H}_{1}\right)$ dalam penelitian ini hasilnya diterima. Penerapan asas keadilan perpajakan berpengaruh terhadap kepatuhan wajib pajak. Hal ini berarti bahwa pengujian hipotesis $2\left(\mathrm{H}_{2}\right)$ dalam penelitian ini hasilnya diterima. Pelaksanaan sosialisasi perpajakan berpengaruh terhadap kepatuhan wajib pajak. Hal ini berarti bahwa pengujian hipotesis $3\left(\mathrm{H}_{3}\right)$ dalam penelitian ini hasilnya diterima. Penurunan tarif pajak, penerapan asas keadilan perpajakan dan pelaksanaan sosialisasi perpajakan atas penerapan Peraturan
Pemerintah Nomor 23 Tahun 2018 secara simultan berpengaruh positif terhadap kepatuhan wajib pajak pada Kantor Pelayanan Pajak Pratama Bulukumba pasca berlakunya peraturan tersebut. Hal ini berarti bahwa pengujian hipotesis 4 $\left(\mathrm{H}_{4}\right)$ dalam penelitian ini hasilnya diterima. Untuk penelitian selanjutnya disarankan untuk menambah variabel lain yang tidak atau belum digunakan dalam penelitian ini, seperti sanksi perpajakan, perilaku wajib pajak, atau variabel lainnya, ataupun dengan menambah ruang lingkup penelitian dengan menggunakan sampel dari Kantor Pelayanan Pajak lainnya.

\section{REFERENSI}

Adiatma, A. Erlian, S.R. Handayani dan K. Hidayat. 2015. Pengaruh Edukasi, Sosialisasi, dan Himbauan Terhadap Kepatuhan Wajib Pajak Dalam Melaporkan SPT Tahunan Pajak Penghasilan (Studi Pada Wajib Pajak Orang Pribadi Yang Terdaftar di Kantor Pelayanan Pajak Pratama Malang Utara). Jurnal Perpajakan (JEJAK). 8 (1). p 1-8 [online].

Ananda, P.R. Dwi, S. Kumadji dan A. Husaini. 2015. Pengaruh Sosialisasi Perpajakan, Tarif Pajak, dan Pemahaman Perpajakan Terhadap Kepatuhan Wajib Pajak (Studi Pada UMKM Yang Terdaftar Sebagai Wajib Pajak di Kantor Pelayanan Pajak Pratama Batu). Jurnal Perpajakan (JEJAK). 6 (2). p 1-9 [online].

Anwar, R. Akbar dan M. Syafiqurrahman. 2016. Pengaruh Sosialisasi 
Perpajakan Terhadap Kepatuhan Perpajakan Wajib Pajak Usaha Mikro Kecil dan Menengah (UMKM) di Surakarta Dengan Pengetahuan Perpajakan Sebagai Variabel Pemediasi. Jurnal InFestasi. 12 (1). p 66-74 [online].

Ardy, A.B. Kristanto dan T.W. Damayanti. 2018. Indonesian Taxpayers' Compliance: A Meta-Analysis. Accounting and Finance Research. 7 (3). p 29-38 [online].

Arikunto, Suharsini. 2002. Prosedur Penelitian, Pendekatan Praktek. Jakarta: Rineka Cipta.

Atawodi, O. Winnie dan S.A. Ojeka. 2012. Factors That Affect Tax Compliance among Small and Medium Enterprises (SMEs) in North Central Nigeria. International Journal of Business and Management. 7 (12). p 87-96 [online].

Banamtuan, Obi. 2018. Pengaruh Sosialisasi Perpajakan Terhadap Kepatuhan WPOP Dalam Pemenuhan Kewajiban PPh 21. Jurnal PETA. 3 (2). p 1-10 [online].

Basri, Y. Mutia dan R.A.S. Surya. 2014. Pengaruh Keadilan, Norma Ekspektasi, Sanksi dan Religiusitas Terhadap Niat dan Ketidakpatuhan Pajak. Akuntabilitas. 7 (3). p 162176 [online].

Benk, Serkan, A.F. Cakmak dan T. Budak. 2011. An Investigation of Tax Compliance Intention: A Theory of Planned Behavior Approach. European Journal of Economics, Finance and Administrative Sciences. 28 (1). $p$ 180-188 [online].
Boediono, G. Tegoeh, R. Sitawati dan S. Harjanto. 2018. Analisis Pengaruh Sosialisasi Perpajakan Terhadap Kepatuhan Wajib Pajak Dengan Kesadaran Sebagai Variabel Mediasi. JPEB Jurnal Penelitian Ekonomi dan Bisnis. 3 (1). p 22-38 [online].

Cahyani, L.P. Gita dan N. Noviari. 2019. Pengaruh Tarif Pajak, Pemahaman Perpajakan, dan Sanksi Perpajakan Terhadap Kepatuhan Wajib Pajak UMKM. E-Jurnal Akuntansi Universitas Udayana. 26 (3). p 1885-1911 [online].

Direktorat Jenderal Pajak. 2020. Laporan Kinerja Direktorat Jenderal Pajak 2019. Jakarta: Direktorat Jenderal Pajak.

Fadilah dan I. Panjaitan. 2016. Pengaruh Keadilan Pajak dan Sanksi Perpajakan Terhadap Kepatuhan Wajib pajak Dengan Kualitas Pelayanan Sebagai Variabel Moderating (Survei Pada Kantor Pelayanan Pajak (KPP) di Wilayah Jakarta Pusat). Media Akuntansi Perpajakan. 1 (2). p 14-28 [online].

Hai, O. Teik dan L.M. See. 2011. Behavioral Intention of Tax NonCompliance among SoleProprietors in Malaysia. International Journal of Business and Social Science. 2 (6). p 142152 [online].

Ibrahim, E. Cahaya dan R.A. Arum. 2018. Kepatuhan Sukarela Wajib Pajak Dalam Pelakasanaan Tax Amnesty pada Kantor Pelayanan Pajak (KPP) Pratama Makassar Utara. Jurnal Administrasi Negara. 24 (2). p 89-100 [online].

Lazuardini, E. Rahmawati, J. Susyanti dan A.A. Priyono. 2018. Pengaruh Pemahaman Peraturan Perpajakan, 
Tarif Pajak dan Sanksi Pajak Terhadap Kepatuhan Wajib Pajak UMKM (Studi Pada Wajib Pajak Orang Pribadi Yang Terdaftar Di KPP Pratama Malang Selatan). EJRM Jurnal Ilmiah Riset Manajemen Fakultas Ekonomi Universitas Islam Malang. 7 (1). p 25-34 [online].

Mardiasmo. 2016. Perpajakan Edisi Revisi Tahun 2016. Yogyakarta: Penerbit Andi.

Muhamad, M. Setiawati, M. Asnawi dan B.J.C. Pangayow. 2019. Pengaruh Sosialisasi Perpajakan, Tarif Pajak, Sanksi Perpajakan, dan Kesadaran Perpajakan Terhadap Kepatuhan Pelaporan SPT Tahunan Wajib Pajak Orang Pribadi (Studi Empiris Pada KPP Pratama Jayapura). Jurnal Akuntansi \& Keuangan Daerah. 14 (1). p 69-86 [online].

Mustofa, F. Achmad, Kertahadi dan M. Maulinarhadi. 2016. Pengaruh Pemahaman Peraturan Perpajakan, Tarif Pajak dan Asas Keadilan Terhadap Kepatuhan Wajib Pajak (Studi pada Wajib Pajak Usaha Mikro Kecil dan Menengah yang Berada di Wilayah Kerja Kantor Pelayanan Pajak Pratama Batu Setelah Diberlakukannya Peraturan Pemerintah Nomor 46 Tahun 2013). Jurnal Perpajakan (JEJAK). 8 (1). p 1-7 [online].

Nababan, Priyance dan S. Dwimulyani. 2019. Pengaruh Sosialisasi Pajak, Pelayanan Fiskus dan Sanksi Pajak Terhadap Kinerja Kantor Pelayanan Pajak (KPP) Dengan Kepatuhan Wajib Pajak Sebagai Variabel Intervening. Prosiding Seminar Nasional Pakar Universitas Trisakti. 2 (2). $p$ 2.47.1-2.47.11 [online].
Puspita, Erna. 2016. Analisis Jalur Pengaruh Sosialisasi Terhadap Kepatuhan Wajib Pajak Bumi dan Bangunan Kota Kediri Dengan Kesadaran Sebagai Variabel Intervening. Jurnal Akuntansi \& Ekonomi FE UN PGRI Kediri. 1 (1). p 1-8 [online].

Ramadiansyah, Dimas, N. Sudjana dan Dwiatmanto. 2014. Analisis Faktor-Faktor Yang Mempengaruhi Wajib Pajak Orang Pribadi Dalam Memenuhi Kewajiban Membayar Pajak (Studi Kasus Pada Kantor Pelayanan Pajak Pratama Singosari). Jurnal e-perpajakan. 1 (1). p 1-7 [online].

Sari, E. Permata dan Y. Mangoting. 2014. Pengaruh Keadilan dan Komunikasi Terhadap Kepatuhan Sukarela Melalui Kepercayaan Sebagai Variabel Intervening. Tax \& Accounting Review. 4 (1). p 114 [online]

Sariani, Putu, M.A Wahyuni dan N.L.G.E. Sulindawati. 2016. Pengaruh Keadilan, Sistem Perpajakan, Diskriminasi, dan Biaya Kepatuhan Terhadap Persepsi Wajib Pajak Mengenai Etika Penggelapan Pajak (Tax Evasion) Pada KPP Pratama Singaraja. JIMAT (Jurnal Ilmiah Mahasiswa Akuntansi) Undiksha. 6 (3). p 1-11 [online].

Siahaan, F.O.P. 2012. The Influence of Tax Fairness and Communication on Voluntary Compliance: Trust as an Intervening Variable. International Journal of Business and Social Science. 3 (21). p 191198 [online].

Suhartini, Dini. 2015. Pengaruh Keadilan Sistem Perpajakan dan Sanksi Pajak Terhadap Kepatuhan Wajib Pajak Badan Dengan Motivasi 
Sebagai Variabel Intervening (Kajian Empiris di KPP Madya Kota Pekanbaru). JOM FEKON. 2 (1). p 1-16 [online].

Tawas, V.B. Josua, A.T. Poputra dan R. Lambey. $\quad 2016 . \quad$ Pengaruh Sosialisasi Perpajakan, Tarif Pajak, dan Sanksi Perpajakan Terhadap Kepatuhan Pelaporan SPT Tahunan Wajib Pajak Orang Pribadi (Studi Kasus Pada KPP Pratama Bitung). Jurnal EMBA. 4 (4). p 912-921 [online].

Wardani, D. Kusuma dan E. Wati. 2018. Pengaruh Sosialisasi Perpajakan Terhadap Kepatuhan Wajib Pajak Dengan Pengetahuan Perpajakan Sebagai Variabel Intervening (Studi Pada Wajib Pajak Orang Pribadi di KPP Pratama Kebumen). Jurnal Nominal. 7 (1). p 33-54 [online].
Warouw, J.Z. Sabhatini, J.J. Sondakh dan S.K. Walandouw. 2015. Pengaruh Sosialisasi Perpajakan dan Sanksi Perpajakan Terhadap Kepatuhan Pelaporan SPT Tahunan Wajib Pajak Badan (Studi Kasus Pada KPP Pratama Manado dan KPP Pratama Bitung). Jurnal EMBA. 3 (4). p 585-592 [online].

Winerungan, O. Lidya. 2013. Sosialisasi Perpajakan, Pelayanan Fiskus dan Sanksi Perpajakan Terhadap Kepatuhan WPOP di KPP Manado dan KPP Bitung. Jurnal EMBA. 1 (3). p 960-970 [online].

Yusro, H. Wachidatul dan Kiswanto. 2014. Pengaruh Tarif Pajak, Mekanisme Pembayaran Pajak dan Kesadaran Membayar Pajak Terhadap Kepatuhan Wajib Pajak UMKM di Kabupaten Jepara. AAJ Accounting Analysis Journal. 3 (4). p 429-436 [online]. 